University of Nebraska - Lincoln

DigitalCommons@University of Nebraska - Lincoln

$11-25-2004$

\title{
Academic Library Web Sites for Distance Learners in Greater Western Library Alliance Member Institutions
}

Mary Cassner

University of Nebraska - Lincoln, mcassner1@unl.edu

Kate E. Adams

University of Nebraska - Lincoln, kadams1@unl.edu

Follow this and additional works at: https://digitalcommons.unl.edu/libraryscience

Part of the Library and Information Science Commons

Cassner, Mary and Adams, Kate E., "Academic Library Web Sites for Distance Learners in Greater Western Library Alliance Member Institutions" (2004). Faculty Publications, UNL Libraries. 74.

https://digitalcommons.unl.edu/libraryscience/74

This Article is brought to you for free and open access by the Libraries at University of Nebraska-Lincoln at DigitalCommons@University of Nebraska - Lincoln. It has been accepted for inclusion in Faculty Publications, UNL Libraries by an authorized administrator of DigitalCommons@University of Nebraska - Lincoln. 
Published in Internet Reference Services Quarterly, 9:3/4 (2004), pp. 33-42. Copyright (C) 2004 The Haworth Press. http://www.haworthpress.com/default.asp Used by permission.

\section{Academic Library Web Sites for Distance \\ Learners in Greater Western Library Alliance Member Institutions}

\author{
Mary Cassner \\ Kate E. Adams
}

\begin{abstract}
Through the library web site, academic libraries present extensive resources and a suite of services to support distance learners. The web site is a vital communication link between the distance student and reference-based instructional component that the librarian provides. This article examines web sites and distance learning library services pages of Greater Western Library Alliance members.
\end{abstract}

KEYWORDS. Academic Libraries, Distance Education Web Pages, Distance Learners, Distance Learning Library Services, Greater Western Library Alliance

\title{
INTRODUCTION
}

The library web site is an important tool for distance learners. Often, the distance education home page is the student's main communication link with the library when accessing library resources and services. The purpose of this article is a review of library web sites that serve distance learners. Of particular interest to the researchers are libraries' distance education web pages, which describe library services and resources available to distance learners. The content of library web sites can be examined to determine what reference information is conveyed as well as how it is presented. The population studied is the Greater Western Library Alliance members, a consortium of 30 research

Mary Cassner is Subject Specialist Librarian and Associate Professor, C.Y. Thompson Library, University of Nebraska-Lincoln, Lincoln, NE 68583-0717 (E-mail: mcassner1@unl.edu). Kate E. Adams is Coordinator for Distance Education and Undergraduate Services and Professor, Love Library, University of Nebraska-Lincoln, Lincoln, NE 68588-4100 (E-mail: kadams1@unl.edu). 
libraries spanning states from the Mississippi River Valley to the Pacific coast. The mission of the Greater Western Library Alliance (GWLA) is "to deliver quality cost-effective services and resources required by clients of member institutions through joint action and collaboration." Members collaborate in resource sharing initiatives in interlibrary loan, electronic licensing, and cooperative collection development (Greater Western Library Alliance, 2004).

The research builds upon earlier studies of library web sites and applies these methodologies to web pages specific to distance learners. The content of library services and resources provided to distance learners is examined, with particular attention given to the broad scope of reference service offered. Data collected was tabulated to compare similarities and differences among the population studied.

It is essential that all students and faculty, regardless of on-campus or offcampus location, have access to quality library resources and services. The originating institution has the responsibility to provide library services and resources to distance learners and distance faculty. As libraries continue to shift into a digital emphasis, librarians have been reflecting on the best way to adjust services to a changing environment with new information needs.

Tenopir and Ennis (2002) found that a significant number of students, because they are comfortable searching the web, are using the web to find information for their assignments rather than electronic periodical indexes. Students view searching the library as less convenient than using commercial search engines. Jackson (2003, p.36) stated, "libraries must gear up to provide a competing level of convenience while retaining the authority and quality of information delivery for which they have been traditionally known."

Library patrons are becoming increasingly vocal in indicating their desire for simple, helpful self-service. Users indicate that they will request assistance only at point of need. Consequently, librarians' efforts should focus on self-help modes to improve and expand services for the student community. At the same time, human assistance still forms a key part of the library user support system (Han \& Goulding, 2003).

The main role of reference librarians has not changed significantly over the years, although there have been substantive changes in the way they carry out the role. Information professionals have always been skilled at identifying users' information needs and recommending quality resources. However, rather than assisting patrons directly, a great deal of the reference's time is now spent behind the scenes, invisible to users (Han and Goulding, 2003). Bunge and Bopp (2001) believe that rather than helping users personally, li- brarians will spend an increasing amount of time designing and engineering interface and help systems. This prospect can benefit distance learners.

Reference services within a digital library environment consist of multiple delivery modes such as face-to-face, email, telephone, web-form, and other computer-based systems. The variety of methods offered is necessary to ensure that services are accessible and convenient for all library users. Each delivery mode has specific strengths and weaknesses, and digital reference is no different. Certain users, whether because of learning style or personal preference, will desire human help even more than online assistance. Others will opt to use an online method when requesting reference help (Lessik, 2000).

One of the newest modes for providing reference service is chat or digital reference. A survey by Janes, Hill, and Rolfe (2001) found digital reference is a most effective approach for repeat library users and to answer short ready reference questions. This mode of reference delivery has application for distance learners.

Kern (2004) noted that there are similarities and differences in providing virtual reference services to on-campus and distance users. Similarities occur in reference interview skills used, instruction in use of resources, and the need to troubleshoot electronic access. Kern identified differences in virtual reference policies and document delivery options.

Reference assistance is essential to meet the bibliographic, informational, and user needs of all learners, whether taking classes on campus or via distance education. Bunge and Bopp (2000) stated that activities comprising reference services fall within three groups. One group consists of information services such as ready reference questions, bibliographic verification, and interlibrary loan/document delivery options. Distance users frequently ask about how to request delivery of material, how to obtain an electronic version of a desired journal article, and what the procedures are for remote access and authentication.

The second group of reference services involves individual or group assistance related to class projects and assignments. The student who seeks to locate journal citations on a specific topic or requests dissertation consultation are examples. User instructions on a particular database is another example of informational service. Posting pathfinders or subject guides on Blackboard or WebCT in support of a class also falls into this category. All of these examples can serve both on- and off-campus students.

In contrast to the second group, the third group of reference services covers general information related to the libraries or the research process itself. 
This may involve individual or group instruction. Examples can be a session that introduces users to the libraries or an individual consultation with a graduate student on discipline-specific library research.

For decades, libraries have been collaborating in various venues, such as bibliographic utilities, collection development, and interlibrary loan. Peters (2003, p.111) states, "Perhaps the question is not whether or not to collaborate, but how to collaborate and with whom." Subramanian (2002) discusses the role of consortia in providing support for distance education. Brunvand, Lee, et al (2001) discuss an academic library consortium in statewide Utah that serves distance learners, while Wittkopf (2002) describes one in Louisiana.

\section{METHODOLOGY}

The population for the study consisted of the Greater Western Library Alliance (GWLA) members, a consortium of Western and Midwestern research libraries. The GWLA web site listed 30 institutions as of June 2004. Criteria for inclusion in the study were that the institution be an academic library, and that the library web site has a distance education page. One GWLA member did not meet the first requirement, and eight GWLA libraries did not contain a distance education home page. The library web sites and distance education pages of twenty-one GWLA libraries were examined.

The authors were interested in knowing how reference service is presented to distance learners. The study focused on the content communicated on distance education pages and library web sites, as reflected by hyperlinks. The authors adapted the general model used in their earlier study, "Content and Design of Academic Library Web Sites for Distance Learners: An Analysis of ARL Libraries" (Adams \& Cassner, 2002). The authors developed a checklist of electronic resources and library services that are available to distance learners as links. Informational links such as contact information for the distance education coordinator and liaison librarians were included. Links to local policy, such as mission statement or definition of what constitutes a distance learner, were noted.

A spreadsheet enumerating the content elements was created with Excel. The presence or absence of each element was recorded. Data were compiled using raw numbers and percentages. Summary notes were prepared describing unique services, search paths, and creative presentations of library information.

\section{RESULTS}

There is great variety in the GWLA libraries' description of distance learning as a header on the distance education pages. The word "distance" is used in 13 of the headings, while "extended" is used by two libraries. Three libraries prefer "Distance Education" and three head the page "Distance Learning Services." Examples of other headings include "Distance Learners," "Distance Users," "Distance Learning Services," and "Distance Learning Support Services." In this article, the authors use several different terms interchangeably.

Nine GWLA library web sites have a top link for distance education, so the page is reached after one click. In eleven instances, the distance education page is two clicks from the library web site top page, and for one institution the distance education page is three levels down.

Each distance education page was examined for inclusion of several features. Fifteen $(71 \%)$ of the distance pages provide a mission statement describing eligibility and scope of services offered to distance learners. One institution provides distance service to faculty, students, and staff who reside more than 30 miles from the institution's city. Another uses the "30 miles away" guide for faculty and students, and also includes students who commute irregularly. A third provides service for students in distance courses held at other system campuses, students who are studying abroad, and students taking correspondence courses. Another institution provides distance service to any affiliates who access library resources remotely, and are not necessarily enrolled in a distance course.

A link to a distance education coordinator or distance team is present on $17(81 \%)$ of the distance education pages, and usually is a pop-up email. Contact information with name, title, phone number, and email address for the coordinator or team is provided in all cases. Only 9 distance learning home pages $(43 \%)$ show a link to liaison librarians.

Nearly half (10) of the distance pages have information on library services specifically for distance faculty. A link to the library's online catalog is present on 20 of the distance learning pages. In 17 cases (81\%), a link to the university web site is available. On only 6 distance learning pages is there a link to the university's services for distance learners. Eighteen of the $21(86 \%)$ distance education pages contain freshness dates, with 11 pages updated during 2004.

Navigation bars are present on 20 of the 21 distance education home pages. Seven distance pages utilize top, bottom, and sidebars. Several pages use one bar only, and several use two. Two distance pages have no bars. 
Each library's web site top page was studied for several features that present specific reference-related information to meet the needs of distance learners. A site search or site index is a link on 19 (90\%) of the GWLA library home pages. Proxy instructions or remote access information do not typically appear on the library's home page; in only four instances $(19 \%)$ is there a top page link. Links to web search engines appear on only $8(38 \%)$ of the GWLA library home pages. The library's address is present on $18(86 \%)$ of the library web site top pages. Online catalogs for other institutions are links on 13 $(62 \%)$ of the GWLA library web sites.

Links to Blackboard or WebCT are present on the top page in 3 of the 21 library web sites. This was surprising since distance courses have been delivered via courseware for the past decade.

The GWLA library web sites were reviewed for instruction-related resources. All 21 have a link for library instruction. Sometimes this refers to site-based instruction, while in other instances instruction is available to remote users. One institution encourages distance faculty to arrange for chat or interactive video instruction sessions. Electronic tutorials are available on $17(80 \%)$ of the 21 web sites examined. Examples of tutorials include the library research process, a literacy tutorial, and how to use the library's online catalog.

Subject guides or pathfinders are present on $19(90 \%)$ of the library web sites, and guides to library research are available on $20(95 \%)$ of the library pages. Other examples of instruction-related resources include online instruction on how to build search strategies and a web search engine feature tip sheet.

Electronic resources are extensive. All of the GWLA library web sites have links for electronic journals, and 20 (95\%) offer an electronic journal finder. Electronic books are accessible at $17(80 \%)$ web sites. All of the library web sites have an article indexes and databases page that typically provides both a subject access list and a title list of databases.

Eligibility for access to electronic resources is explained, and users are informed that they will need to provide their name and university identification and/or pin number.

Several GWLA libraries have federated searching or multiple database search capability. One library uses "multiple database search" as a link on the library's home page. Another library provides a link "multiple indexes" as one of the options on the indexes to articles page, while one library labels the link as "search multiple databases."
Electronic reserves are available at all 21 of the web sites studied. Each GWLA library web site has a section of electronic reference materials. Examples include encyclopedias, atlases, almanacs, and dictionaries. Links to digitized collections are present on $17(80 \%)$ of the web sites.

Multiple access points to reference assistance are essential for distance users. Reference via email or web-form is available at all of the GWLA libraries. A phone number for reference service is provided in all instances. Eight GWLA libraries (38\%) have a toll-free phone number. Consultation with a librarian is a service at all of the libraries. Twenty web sites have a link to a list of liaison librarians on one of the lower pages, and not necessarily from the top page.

Chat or virtual reference is available at $15(71 \%)$ of the GWLA libraries. Three libraries provide the service on a $24 / 7$ basis, as a collaborative statewide effort. Two GWLA libraries offer chat service seven days a week, with hours of service during the afternoon through early evening. Ten libraries provide the service Monday-Thursday or Monday-Friday (but not on weekends), ranging from 20 hours to 65 hours weekly. Of these ten, hours of service begin at noon or 1 p.m. or 2 p.m., although one library staffs chat at 8 a.m. and two open the service at 10 a.m. Often, some kind of authentication is required for the service. While checking the web sites for the study, the authors observed some changes in hours of chat service, presumably to better match the demand for service.

Delivery of books and articles from the home library's collection is typically available to distance users. State-wide or system-wide borrowing of books is an option for distance users at 15 (71\%) of the GWLA libraries. However, state-wide or system-wide borrowing of articles is an option for distance users at only $11(52 \%)$ of the libraries.

All of the GWLA libraries provide interlibrary loan request forms for distance users. At 20 libraries, interlibrary loan allows borrowing of articles, while at 19 libraries, interlibrary loan borrowing of books is an option for distance users. Options for article delivery are web, USPS, and fax. Returnables are delivered using expedited delivery, with this service typically limited to users within the United States. Eight of the GWLA libraries are using ILLiad, and a registration form is usually required. 


\section{DISCUSSION}

Through library web sites and distance education pages, GWLA libraries provide extensive resources and a suite of services to support distance learners. Dew (2002) recommended certain components that should appear on web pages designed to support distance learners. These included a statement of eligibility for distance service, links to electronic resources, remote access and authentication procedures, and information about document delivery services. Additionally, instruction-related resources such as library research tutorials, discipline-specific pathfinders, and electronic reference materials are vital elements of library service to distance students.

Increasingly, students expect to be able "to do it themselves" (self-service). They want to find what they need for class assignments or projects, through independent searching. Full-text library databases and off-campus access to the library catalog were found to be the most useful library services, according to a survey of distance students at the University of Maryland University College. Web-based library instruction was preferred over alternate methods of instruction. Students indicated a desire for web-based information about library services versus other formats (Kelley \& Orr, 2003).

Libraries provide multiple ways for users to obtain needed research materials by providing electronic journals, full-text and citation databases, ebooks, digital collections, and web-request forms. If the user cannot find the needed information or item from the library web site, often that is when contact is made with a librarian. The librarian is the intermediary who provides the point-of-need instructional component, often directing the user back to a specific electronic resource or navigating the user through the steps for authentication or placing a request for delivery of library materials. It is the reference-based instructional component the librarian provides that is essential.

In the immediate future, it is likely that librarians will allocate more time and staffing resources to implementing and designing interface and help systems. In part this will reflect librarians' dual desires to improve users' information skills and to encourage students to make full use of the digital library. In part, user demand for additional full-text resources and ease of library access has been growing and will continue to do so. Libraries are responding to these trends by creating or purchasing multiple database search capability and electronic journal finders. These provide the remote user with easy-access, one-stop, self-help information services, through a combination of web surfing functionality and high quality library resources.
Another trend that libraries face is the rapid adoption of course management software by many universities. Relatively few libraries currently are taking advantage of Blackboard or WebCT capabilities. Examples of potential usage for libraries include mounting resources such as pathfinders, using as an assessment tool, and using as another means of communicating with students. As more librarians develop instructional design skills, there is great opportunity for librarians to partner with faculty. Improved integration of course management software is fundamental to libraries reaching distance users.

Consortial collaboration allows libraries to manage and distribute costs of products and keeping staff expertise up-to-date. While a distance user may search the library catalog or database 24/7, library budgets are not adequate for such a level of staffing. Consortial collaboration is a way to leverage staff to meet user demand in a complex web-based environment.

\section{CONCLUSION}

The library's web site and distance education home page are key communication links for distance learners. These, combined with reference-based instruction and liaison librarian assistance, give the distance user access to numerous resources. As librarians add new services and electronic finding tools, the distance learner stands to benefit.

\section{REFERENCES}

Adams, Kate E. and Mary Cassner. "Content and Design of Academic Library Web Sites for Distance Learners: An Analysis of ARL Libraries," Journal of Library Administration 37 no.1/2 (2002): 3-13.

Brunvand, Amy, Daniel R. Lee, et al. "Consortium Solutions to Distance Education Problems: Utah Academic Libraries Answer the Challenge," Journal of Library Administration, 31 no.3/4 (2001): 75-92.

Bunge, Charles A. and Richard.E. Bopp. "History and Varieties of Reference Services." In Reference and Information Services: An Introduction, (Englewood, CO: Libraries Unlimited, 2001): 3-25.

Dew, Stephen H. "Documenting Priorities, Progress, and Potential: Planning Library Services for Distance Education," Journal of Library Administration 37 no.1/2 (2002): 217-243.

Greater Western Library Alliance [homepage] 1 July 2004, < http://www.gwla.org $>$. (23 July 2004). 
Han, Lifeng and Anne Goulding. "Information and Reference Services in the Digital Library.” Information Services \& Use 23 (2003): 251-262.

Jackson, Mary E. “The Advent of Portals." Library Journal 127, no.15 (2002): 36-39.

Janes, J., C. Hill, and A. Rolfe. "Ask-an-Expert Services Analysis.” Journal of the American Society for Information Science and Technology 52 (2001): 1106-1121.

Kelley, Kimberly B. and Gloria J. Orr. "Trends in Distant Student Use of Electronic Resources: A Survey.” College \& Research Libraries 64 (2003): 176-191.

Kern, M. Kathleen. "Chat It Up!: Extending Reference Services to Assist Off-Campus Students." In Eleventh Off-Campus Library Services Conference Proceedings: Scottsdale, AZ, May 5-7, 2004, (Mount Pleasant, MI: Central Michigan University, 2004): 161-168.

Lessick, Susan. “Transforming Reference Staffing for the Digital Library.” In Digital Reference Service in the New Millennium: Planning, Management, and Evaluation, (New York: Neal-Schuman, 2000): 25-36.

Peters, Thomas A. "Consortia and Their Discontents." Journal of Academic Librarianship 29 (2003): 111-114.

Subramanian, Jane M. "The Growing and Changing Role of Consortia in Providing Direct and Indirect Support for Distance Higher Education." Reference Librarian, no.77 (2002): 37-60.

Tenopir, Carol and Lisa Ennis. “A Decade of Digital Reference: 1991-2001.” Reference \& User Services Quarterly 41 (2002): 264-273.

Wittkopf, Barbara J. "Resource Sharing in Louisiana." Resource Sharing \& Information Networks 16 (2002): 103-120. 